\title{
TUDOMÁNYTÖRTÉNET
}

\section{Deme László száz esztendeje}

Deme László a vele egy évben (1921-ben) született Benkő Loránddal együtt annak a nagy nyelvésznemzedéknek kiemelkedő tagja, amely a 20. század húszas éveiben született, és mind egyéni teljesítményével, mind pedig kollektív munkákban való részvételével egyedülálló eredményeket ért el. (A generáció huszonöt éves tevékenységéröl 1. DEME 1974a.)

Az alábbiakban elöbb az 1941-1981 közötti negyven év Deme-eredményeire utalunk (1.), majd a nyugdíjba vonulás utáni évtizedekről esik szó (2.), ezt követően munkásságának folytatóiról szólunk (3.), végül rövid összefoglalás zárja a gondolatmenetet (4.).

\section{Eredmények, 1941-1981.}

Deme tanár úr Rozgonyiné Molnár Emmának válaszolva megírta, milyen témákat látna szívesen a jubileumi kiadványban, 1996-ban (B. FEJES - R. MOLNÁR szerk. 1996). A továbbiakban nagy vonalakban a professzor javaslatait követjük. (Ezek tekintettel vannak a lehetséges terjedelemre is.)

1.1. A felsorolás a hangtan területén megjelöli a szorosabban vett fonetikai, fonológiai témára utaló tanulmányát: A magyar fonémák rendszeréhez és rendszerezéséhez (DEME 1971-1972; angol nyelven Tallinnban, 1975-ben jelent meg, 1. DEME 1975a). Különbséget tesz a magyar fonémák sajátosságai között abból a szempontból, hogy ezek a jellemzők (a cikk írása idején már feltűnő) számítógépes elemzések szerint sem ugyanolyan szereppel, nem ugyanolyan fontosságú részrendszereket különböztetnek meg egymástól. A magánhangzók körében a rövid-hosszú szembeállítások szerepe más, mint a palatális vs. veláris szembeállításoké, a hangszín szerinti tagolódás másként érvényes, mint a labiális vs. illabiális tagolódás stb. DEME LÁszLÓ bölcsészdoktori értekezése a szerző huszonkét éves (!) korából való (DEME 1943). Az egészen rendkívüli pályakezdést ekkor már számos megjelent cikk is kiemeli (1941-ben 6, 1942-ben 5, 1943-ban 8 publikáció, köztük több fonetikai vagy morfofonetikai témájú, l. DEME: Pályakép 2000).

1.2. Az a laktan területén DEME a nulla morfémás magyar igealakokat tárgyaló cikkét említi, mind strukturális helyzetük, mind kommunikációs szerepük szerint. A nyelvi rendszer elvét és a nyelvhasználat lényeges összetevőit ott is, másutt is egymásra vonatkoztatja; kiemelhető a nyelvjáráskutatásban a fonetikai lejegyzés megalkotásának eredménye is, a később tárgyalandó helyesírási elv (a fonematikus írásmód elve) közlése is. Korai német nyelvü összefoglalójában (DEME 1944), későbbi angol nyelvü változatában is (DEME 1972) érvényesíti ezt a megközelítést.

1.3. A mondattanból a professzor javaslatában a mondat meghatározásának, valamint az egyszerü és az összetett mondat szinteződésének és tömbösödésének témája olvasható. Deme mondatdefiníciójában - amint egész szemléletében - a „mirevalóság” áll az első helyen, s a fölépítés, szerkezet, összetevők csak ez után következnek. A kiin- 
dulást PAIS DEZSŐ ősmondat-fogalma jelenti (1. például DEME 1966a, 1976 stb.). DEME „mirevalóság” fogalmából ered a funkcionális megközelítés elve.

DEME a mondatot a szöveg részének tekinti, s ilyenként a mondat lényegét a partnerek közötti információcserében betöltött szerepe adja, ez a beszerkesztettség. Így a mondat szövegbeli szerepén, a közlés, a kifejezés és a befolyásolás funkcióján alapszik a fölépítés, a szerkezet, azaz a megszerkesztettség.

Az egyszerű mondat szinteződésének és tömbösödésének vizsgálata után elemezte DEME az összetett mondat szinteződésének és tömbösödésének kérdését (DEME 1966b). Az elöbbinek a szinteződése az állítmányközpontú mondathoz, azaz a mondathoz mint igefüggvényhez vezetett. DEME az (igei) állítmány abszolút fölérendelt szintjéhez a mondatrészek és a szerkezetrészek szintjét kapcsolta.

Az egyszerű mondat szinteződésének és tömbösödésének vizsgálatát Deme összekapcsolta a nyomatékviszonyokkal, a hanglejtéssel és a szórenddel, ilyen módon jelentősen megelőzte a több évtized múltán ehhez eljutó kutatókat. Kulcsfogalmai: bevezetés (1. topik) - új - Főhangsúlyos rész (a legfontosabb információ, 1. fókusz) + az ige - egyéb részek $=\mathbf{b}-\mathbf{u}-\mathbf{F}(+$ ige $)-\mathbf{e}$.

Az összetett mondatban a szinteződés és tömbösödés jelenségéhez kapcsolódott a főkapcsolás és alkapcsolás / főviszony és alviszony megkülönböztetése; a főmondat szintje, az első mellékmondat szintje, a második mellékmondat szintje stb.

DEME LÁSZLÓ 1971-ben megjelent könyve (DEME 1971) a nyelvhasználat (= a beszéd) elsődlegességéből kiindulva számos olyan eredményt is leírt, amelyek a „,szabálytalan” mondattípusokat jellemezték, például „elszabadult mellékmondatok”, kihagyott információk stb. Több szövegtípusban tárt fel olyan sajátságokat, amelyeknek mutatóival (tagoltság, zsúfoltság, szintmélység stb.) igyekezett megragadni a kommunikációban a befogadót segítő vagy korlátozó tényezőket.

1.4. A szövegtan területén - ahogyan a mondat meghatározásában - feltűnő vonás a funkcionalitás elsőbbsége: a mirevalóság a mondatban, a mondattömbben, a bekezdésben, a szövegmüben. Itt a következő cikkét emelte ki a professzor: Szövegszerkezeti alapformák és stílusértékü változataik (DEME 1974c). Ez az akadémiai nyelvtanban megírt fejezet után (DEME 1962) a konferencia-előadás rövidségével világítja meg a 19. század közepe óta ismert jelenséget (FOGARASI-féle hangtörvény, BRASSAI SÁMUEL az inchoativumról és a mondatzömről, DEZSÖ LÁSZLÓ az aktuális tagolásról, CHOMSKY topik-comment, majd topik-predikátum tagolása a magyar kutatók világában stb.): a legfontosabb információ helye az ige elött van.

1.5. A nyelvfilozófia, nyelvelmélet területéről DEME javaslatai a Nyelviség és megismerés (1973) című közleményében olvashatók. Összefoglalóan PAIS DEZSŐ és ANDRUS DE LAGUNA nyomán A nyelvről - felnőtteknek (1966a), Az általános nyelvészet alapjai (1969), majd A beszéd és a nyelv (1976) lapjain ír ezekről a témákról. Az utóbbi címben jelentése van a sorrendnek: DEME szerint a beszéd elsődleges a nyelvvel szemben genetikusan is, funkcionálisan is.

1.6. A dialektológus és nyelvtörténész professzor mindenekelőtt a nyelvatlaszra utal: az anyag felhasználása sokoldalú lehet, nemcsak a szinkrón, hanem a történeti nyelvjáráskutatásban is. Első helyre teendő DEME gyűjtői, ellenőrzői, szerkesztői, teoretikus munkásságában A magyar nyelvjárások atlasza (MNyA. 1-6., 1968-1977, szerk. IMRE SAMUval); korábban jelezte mindezt a már huszonévesen közölt A magyar 
nyelvjárási anyag feldolgozása és felhasználása (1949); néhány év múlva A magyar nyelvjárások néhány kérdése (1953), A magyar nyelvatlasz munkamódszere (BÁRCZI-DEME szerk. 1955), Nyelvatlaszunk funkciója és további problémái (1956, az értekezés nyomán védte meg kandidátusi címét); a tanulságok összefoglalásaként pedig A magyar nyelvjárások atlaszának elméleti-módszertani kérdései (társszerzőkkel és IMRE SAMUval mint társszerkesztővel, 1975b). DEME LÁSZLÓ az egyik kiemelkedő vezetője a grandiózus vállalkozásnak az 1950-es évektől kezdve BALOGH LAJOSsal, BENKÖ LORÁNDdal, IMRE SAMUval, KÁLMÁN BÉLÁval, LÖRINCZE LAJOSsal, VÉGH JÓZSEFfel és másokkal együtt. A nyelvatlasz gyüjtő szakaszában született A XVI. század végi nyelvi norma kérdéséhez című kötete (1959). A további részletezés alól fölmentenek KISS JENŐ írásai (KISS 2012, 2021); és SZABÓ JÓZSEF cikke (SZABÓ 1992).

1.7. A n y elvmüve lé s témakörében DEME LÁSzLÓ javaslata a nyelvi norma történetére utal, említi a nyelvhasználati kultúráról szóló cikkét: Átrétegződés vagy lepusztulás (1988). Egész pályáján folyamatosan foglalkoztatták a nyelvmüvelés elvi és gyakorlati kérdései. A Kárpát-medence egészében jellemző nyelvhasználati kérdésekről is írt (1970), beleértve a szakmai nyelvi rétegek aktuális problémáit (1964b, 1982, 1987) stb.

1.8. A magyar helyesírás elvi és gyakorlati kérdéseiben az akadémiai helyesírási szabályzat megújítása idején (1954 előtt és után, 1984 előtt és után) Deme tanár úr a munkálatok egyik vezetője és fő résztvevője. Folyamatosan gondozta a helyesírás területét (BENCÉDY-DEME-FÁBIÁN 1966, BENKÖ-DEME-FÁBIÁN 1961; DEME 1964a; DEME-FÁBIÁN-TÓTH szerk. 1988, 1999).

1.9. Az anyanyelvi nevelés korhatártól függetlenül szívügye volt DEME tanár úrnak. A nyelvi ismeretterjesztés egyik legismertebb alakjaként szóban és írásban folyamatosan foglalkozott a magyar nyelv tanításának elvi és szervezési gondjaival. Tantervi programok, tankönyvek megvitatásában vállalt feladatokat; ugyanakkor igyekezett minden korosztály számára eligazító tanácsokkal szolgálni (1966a, 1974b, 1976, 1978, DEME-GRÉTSY-WACHA 1987/1999).

1.10. Szegedhez köthető különleges eredménye DEME LÁSzLÓnak a Kincskereső címü folyóirat szerkesztés e 1975-1981-ig. Az őt követő föszerkesztő, SIMAI MıHÁLY így értékelte elődjét: „Emberi kvalitásai, bölcsessége, óriási tudása révén Deme László nagy hatást gyakorolt a szerkesztőség munkastílusára s a lap harmonikus fejlödésére" (vö. MNy. 2011: 373).

1981-ben a JATE BTK-n a tanszékvezetőt így köszöntötték a munkatársai: „Deme László a szövegkészítés céhmestere". A szövetkészítési céhszabályzat aktualizált változata nagy tetszést aratott: a tanszékétől búcsúzó professzor is örült az ötletnek.

\section{Eredmények, 1981-2011.}

1981-ben jelentős változás kezdődött DEME LÁSzLÓ pályáján, ő maga így ír erről: „[a hazai tudománypolitikából és egy fontos nemzetközi munkatervböl - N. L. J. megj.] fokozatosan kikapcsolódtam. A hazai szervekből-szervezetekből azért, mert időközben olyan fokon jutott túlsúlyra bennük a »világorientációs« tendencia, hogy (hajdan világszintünek elismert) hazai hagyományaink és eredményeink (egyre hivatalosabbnak számító) belföldi értékelése nullára íródott le, folytatóik és képviselöik kiszorultak vagy kihúzódtak a folyamatok irányításából; és már, utolsó mohikánként, hatástalannak bizonyult ennek befolyásolására törekedni, és céltalannak ellene berzenkedni” (Végszó, in: DEME: Pályakép 2000: 7). 
A leírt tényezőkön kívül szerepet játszhatott szakmai csalódás (nem került az akadémiai tagok közé, jóllehet kétszer is fölterjesztette őt Benkő Loránd és Imre Samu akadémikus), ehhez járulhattak más méltánytalanságok. Nem kevésbé szerepet játszhatott a pályatársak körében DEME LÁSzLÓ ironikus, néha harcias stílusa, az ekkoriban fölerősödő támadások a nyelvmüvelés ellen stb.

DEME tanár úr számos területen folyamatosan dolgozott 1965-től a magyar kiejtés ügyéért, s jelentős energiákat fordított a Magyar Rádió nyelvi bizottságában és általában a közéleti megszólalásokban érvényes nyelvhasználati tendenciák elemzésére. Személyisége különleges hatást gyakorolt az anyanyelvi mozgalmakra a köznevelés és a felsőoktatás intézményeiben, elsősorban a Kazinczy-verseny népszerüsítésében. Nem sajnálta az időt a levelezésre, a rendszeres szereplésre a rádiómüsorokban, a magyar nyelv hetén, a társasági rendezvényeken. (Részletesebben 1. WACHA 2021.)

PÉCHY BLANKA közvetlen szakmai vezetőjeként, azután KEREKES BARNABÁs és mások segítségével teljes energiájával szolgálta a szép magyar beszéd ügyét; ennek érdekében jelentős mennyiségü itthoni és határainkon túli szereplést vállalt. Külön említést érdemel a pedagógusokkal kiépített kapcsolatrendszere; folyamatos személyes összeköttetésben müködött együtt a tanárokkal. SZABó JÓzSEF így ír erről: „Tudósi és emberi kisugárzó, nevelő hatása sohasem maradt az egyetem vagy más intézmény falain belül, mert írásainak és előadásainak kristálytiszta logikáját, gondolatgazdagságát - mindennapi munkájukba építve - nemcsak sok szakember, kolléga, hanem a pedagógus-továbbképzésben részt vevők százai, tanítványainak ezrei vitték s viszik tovább” (SzABó 1992: 219).

\section{Folytatók és folytatások}

Számadatokkal igazolható, hogy 2021-ben számos fontos jubileuma van a száz éve született DEME tanár úrnak: 1941-ben, húszéves korában jelentek meg első cikkei (80 éve). 1971-ben, ötvenéves korában jelent meg a sikeresen megvédett MTA doktori értekezése (50 éve), 1981-ben, hatvanéves korában vonult nyugdíjba (40 éve), idén novemberben tíz éve, 2011-ben személyében távozott közülünk.

Kétségtelen, hogy a mostanában közölt cikkek, tanulmányok szerzői kevesebbet hivatkoznak DEME LÁSZLÓ írásaira, gondolataira. Mégis van lehetőségünk az alábbiakban szemléltetni néhány olyan területet a munkásságából, amelyeken jól érzékelhetők tevékenységének máig élő hatásai. Nem törekedhetünk teljességre, az alábbi sorozat folytatható, bővíthető.

3.1. Szövegkutatás szintaktikai megközelítéssel. MÁTÉ JAKAB megállapítása szerint: „Magyar nyelvtudomány-történeti tény (vö. MÁTÉ 1991a, 1991b), hogy hazánkban a 60-as évek közepétől kezdődően a szövegkutatás egyik lehetséges irányát - valamint ösztönzést a különböző müfajú szövegek kutatásához - Deme László összetettmondat-kutatásai jelölték ki” (DEME 1966b: 392-404; idézi BÉKÉSI 2016: 106). BÉKÉSI IMRE a kettős szillogizmus elmélete kiformálódásának idején is napihírek, majd esszérészletek mondatviszonyainak elemzését végezte el (BÉKÉSI 1982, 1986 stb.). Innen jutott el a szövegszemantika területére, az explicit és implicit információk ellentétes szerkezetekben feltárható szillogisztikus következtetéseiig (BÉKÉSI 1993). DEME LÁSZLÓ ezt így ismerte el: „Békési Imrének, felnőtt tanítványaim legjobbikának küldöm [...] szeretettel és annak elismerésével, hogy a tizenegynéhány évvel ezelött általam a mikrokonstrukcionális irányban keresett utat a továbbfejlesztéshez ő nagyobb sikerrel találta meg a logikoszemantikus oldalon - Per aspera ad astra!” (DEME 1979/1996: 81). 
A tömbösödés vizsgálatai BÉKÉSI IMRE kandidátusi értekezésében a mondatrészek, a tagmondatok, a mondatok tömbjeit egyaránt elemezték. Amint fentebb említettük, az explicit tagmondatok, szövegmondatok információinak implicit tagmondatokkal, mondatokkal való kiegészítése vezetett el a kettős szillogizmus elméletéhez és alkalmazásaihoz (vö. BÉKÉSI 2010).

3.2. Mondatszerkezeti sajátságok gyakorisági vizsgálata (1971). DEME LÁSZLÓ sok kiadást megért munkájának címében nem véletlen a sorrend: A beszéd és a nyelv (1976). Intenciói alapján B. FEJES KATALIN elsőként írt tankönyvet a szöveg - mondat - szó - hang sorrendi tagolás érvényesítésével: Anyanyelvünk. A 2. osztály számára. B. FEJES később gyermekszövegekben és tankönyvi szövegekben vizsgálta DEME 1971-es munkájának mutatóit (zsúfoltság, szerkesztettség, tagoltság, szintmélység stb.). Az MTA 6. sz. kutatási föiránya a tankönyvi szövegek elemzését ezeknek a mutatóknak az alkalmazásával is végezte; jó példa a 6. osztályos fizika-tankönyv nyelvi elemzése a 70es évek végén. A tankönyvi szövegek megfogalmazásainak, ezek tanulhatóságának mai elemző vizsgálata visszavezethető az 1971-es DEME-munka alapvetésére. SzABÓ JózSEF nyelvjárási szövegekre alkalmazta mestere MTA doktori értekezésének elemző eljárásait, s így nyerte el a nyelvtudomány kandidátusa címet.

3.3. A dialektológiai kutatásokból. SzABÓ JózSEF a professzora dialektológiai kutatásaitól ösztönözve készítette el 1989-ben akadémiai doktori értekezését (megjelent Magyarországi és jugoszláviai magyar nyelvjárásszigetek címmel 1990-ben). DEME LÁSZLÓ segítette a Szombathelyen működő regionális köznyelviségi kutatókat és kutatásokat; ennek nyomán öten értek el tudományos minősítést. A rendszeresen sorra kerülő dialektológiai szimpóziumok munkájában előbb személyesen, később már csak írásbeli megjegyzéseivel vett részt.

3.4. A grammatikai folytatás okbó 1 . DEME LÁSZLónak a fentebb említett szintaktikai munkásságát folytatta M. KORCHMÁROS VALÉRIA; egyetemi tankönyvet állított össze (M. KorCHMÁROS 1991).

A Magyar grammatika (MGr.) több ponton alkalmazta DEME elveit, például az egyközpontú mondat, az alany bővítményjellege, a melléknév és a számnév kategóriájának, közös sajátságaiknak a hangsúlyozása stb.

3.5. A nyomatékos mondatok tömbjeinek leírása. A fentebb említett MMNyR. 2. kötetének záró fejezete is, illetve számos rövidebb Deme-írás is foglalkozott a nyomatékos mondatok hangsúlyozási és hanglejtési kérdéseivel. VARGA LÁSZLÓ nevezetes tanulmánya (1989) lényeges pontokon hivatkozik az akadémiai nyelvtanra. VARGA tanár úr legújabb tanulmányában (Deme László a magyar mondat hangsúlyozásáról és hanglejtéséről. Kézirat; megj. alatt) ugyancsak értékes alapokra talál DEME megállapításaiban.

3.6. Deme László és a helyesírási versenyek. DemE tanár úr segítette tanácsaival és előadásaival a Nagy J. Béla helyesírási versenyt (Eger, 1987-től), az Implom József Középiskolai Helyesírási Verseny Kárpát-medencei döntőit (1992-től). Kiemelhető a fonematikus írásmód elvének ismertetése (1964a): ez egyesíti magában a kiejtés szerinti és a szóelemző elvet. Figyelemre méltó, hogy a 2015-ben megjelent 12. kiadású szabályzatban számos megfogalmazás vagy szó szerint, vagy tartalmilag ennek a DEME tanár úrtól 1964-ben kifejtett elvnek az értelmében rendelkezik (1. Cs. NAGY LAJOS előadását a 2021. júniusi Deme-konferencián). 
3.7. Deme László munkái újabb kiadványokban. Jellemző az 1981 utáni évtizedekre, hogy számos kiadványban, didaktikus feldolgozásban jelentették meg a munkatársak, tanítványok DEME tanár úr gondolatmeneteinek rövid részleteit (1. B. FEJES 2015, DEME 1994, 2003, „Diófát ültetek” 2012, „Diófát ültetek” 2021).

Közleményeinek listája elérhető a következő helyeken: TAKÁCS KÁROLYNÉ 1980; GulYÁs ZsuZSANNA 1996; DEME: Pályakép 2000.

\section{Deme László személyiségéről}

Ifjúkorától kezdve munkatársait a feltünő tehetsége nyügözte le: problémalátása, gyors reagálókészsége, kezdeményező invenciója. Szóban kiváló előadó, vonzó egyéniség; írásaiban elegáns, logikus. Munkabírása egyedülálló volt. Egy beszélgetésben kérdésre válaszolva így magyarázta rendkívüli termékenységét: „Ha én kapok egy feladatot, leülök, és megcsinálom".

Tudatosan örizte a szép beszéd ügyéért küzdőket, a közös munkára áldozatkészen vállalkozók munkakedvét. Az ő kedvéért mindenki igyekezett a legjobbját nyújtani: így jött létre és sugárzott a találkozásokból a „fészekmeleg” légkör (D. L. kifejezése). Önzetlenségét átvették tőle a kisebb-nagyobb közösségek is. Kányádi Sándor Gyulán mondta a megnyitó résztvevőinek 2003-ban az Implom József Középiskolai Helyesírási Verseny Kárpát-medencei döntőjén: „Ti vagytok a magyar nyelv testőrgárdája.” Örizzék a kazinczysok is Deme László örökségét - mint a magyar nyelv testőrei!

\section{Hivatkozott irodalom}

BÁRCZI GÉZA - DEME LÁSZLó szerk. 1955. A magyar nyelvatlasz munkamódszere: tanulmánygyüjtemény. Akadémiai Kiadó, Budapest.

BÉKÉSI IMRE 1982. Szövegszerkezeti alapvizsgálatok. Nyelvészeti Tanulmányok 20. Akadémiai Kiadó, Budapest.

BÉKÉSI IMRE 1986. A gondolkodás grammatikája. Tankönyvkiadó, Budapest.

BÉKÉSI IMRE 1993. Jelentésszerkezetek interpretációs megközelitése. Egy modell az argumentatív szövegtípus tanulmányozásához. JGYTF Kiadó, Szeged.

BÉKÉSI IMRE 2010. A kettős szillogizmus értelmezése és alkalmazásai. Szemiotikai Szövegtan 19.

BÉKÉSI IMRE 2016. Nyelvész mestereim. Tudománytörténeti adatok és emlékek. Szegedi Egyetemi Kiadó - Juhász Gyula Felsőoktatási Kiadó, Szeged. 31-35, 101-110, 141-146, 184-192.

BENCÉDY JÓZSEF - DEME LÁsZLÓ - FÁBIÁN PÁL 1966. A magyar helyesírás rendszere. Nyelvtudományi Értekezések 54. Akadémiai Kiadó, Budapest.

BENKŐ LORÁND - DEME LÁSZLÓ - FÁBIÁN PÁL szerk. 1961. Helyesírási tanácsadó szótár. Terra, Budapest.

DEME LÁSzLó 1943. A hangátvetés a magyarban. A Magyar Nyelvtudományi Társaság Kiadványai 69. Magyar Nyelvtudományi Társaság, Budapest.

Deme LÁsZló 1944. Die ungarische Sprache. Kleine Ungarnkunde 15. Athenaeum, BudapestHamburg.

DEME LÁszLó 1949. A nyelvjárási anyag felhasználása és feldolgozása. A Néptudományi Intézet kiadványai II. 27. Kelet-európai Tudományos Intézet, Budapest.

DEME LÁszLó 1953. A magyar nyelvjárások néhány kérdése. Nyelvtudományi Értekezések 3. Akadémiai Kiadó, Budapest.

DEME LÁszLó 1956. Nyelvatlaszunk funkciója és további problémái. Akadémiai Kiadó, Budapest. 
DEME LÁszLó 1959. A XVI. század végi nyelvi norma kérdéséhez. Nyelvtudományi Értekezések 20. Akadémiai Kiadó, Budapest.

DEME LÁSZLó 1962. Hangsúly, szórend, hanglejtés, szünet. In: MMNyR. 2. 458-521.

DEME LÁsZLó 1964a. Helyesírási rendszerünk logikája. [1-2.] Magyar Nyelvőr 88: 229-247, $357-$ 376. (Klny: A Magyar Nyelvtudományi Társaság Kiadványai 110. Magyar Nyelvtudományi Társaság, Budapest, 1965.)

DEME LÁSZLÓ 1964b. Szórendi problémák az értekező prózában. In: KISMARTY LORÁND szerk., Müszaki Nyelvőr. Müszaki Könyvkiadó, Budapest. 114-135.

DEME LÁszLó 1966a. A nyelvröl - felnötteknek. Gondolat, Budapest.

DEME LÁSzLó 1966b. Szinteződés és tömbösödés az egyszerü mondatban. Magyar Nyelvör 90 : 275-287, Szinteződés és tömbösödés az összetett mondatban: uo. 392-404.

DEME LÁSZLÓ 1967. A nulla morfémás magyar igealakok strukturális helyzete és kommunikációs szerepe. In: KÁROLY SÁNDOR szerk., Az ige grammatikája és szemantikája. Nemzetközi munkaértekezlet. MTA Nyelvtudományi Intézet - ELTE, Budapest. 12-22.

Deme LÁszLó 1969. Az általános nyelvészet alapjai. Slovenské Pedagogické Nakladatełstvo, Bratislava.

DEME LÁSzLó 1970. Nyelvi és nyelvhasználati gondjainkról. Madách, Bratislava.

DEME LÁsZLó 1971. Mondatszerkezeti sajátságok gyakorisági vizsgálata. (Magyar szövegek alapján.) Nyelvészeti Tanulmányok 15. Akadémiai Kiadó, Budapest.

DEME LÁsZLó 1971-1972. A magyar fonémák rendszeréhez és rendszerezéséhez. Néprajz és Nyelvtudomány 15-16: 89-99.

DEME LÁsZló 1972. Standard Hungarian. In: BENKŐ, LORÁND - IMRE, SAMU eds., The Hungarian Language. Akadémiai Kiadó, Budapest. 255-297.

DEME LÁSZLÓ 1973. Nyelviség és megismerés. Filozófiai Közlemények 10/1: 51-73.

DEME LÁszLó 1974a. Magyar nyelvészeti kutatómunkánkról. A Magyar Nyelvtudományi Társaság Kiadványai 137. Magyar Nyelvtudományi Társaság, Budapest.

DEME LÁSzLó 1974b. Szónokok, elöadók kézikönyve. Kossuth, Budapest.

DEME LÁSZLÓ 1974c. Szövegszerkezeti alapformák és stílusértékủ változataik. In: IMRE SAMU SZATHMÁRI ISTVÁN - SZÜTS LÁSZLÓ szerk., Jelentéstan és stilisztika: a magyar nyelvészek II. Nemzetközi Kongresszusának elöadásai (Szeged, 1972. augusztus 22-25). Nyelvtudományi Értekezések 83. Akadémiai Kiadó, Budapest. 114-118.

Deme LÁszLó 1975a. The Phonological System of Hungarian. In: NorVIK, M. ed., Congressus Tertius Internationalis Fenno-Ugristarum. Tallinnae habitus 17-23, VIII. 1970. Pars 1. Tallinn, 582-586.

DEME LÁSZLÓ - IMRE SAMU szerk. 1975b. A magyar nyelvjárások atlaszának elméleti-módszertani kérdései. Akadémiai Kiadó, Budapest.

DEME LÁszló 1976. A beszéd és a nyelv. Tankönyvkiadó, Budapest.

DEME LÁszLó 1978. Közéletiség, beszédmód, nyelvi müveltség. Kossuth, Budapest.

DEME LÁSZLó1979/1996. A rádióhírek fogalmazásáról, 1979. In: R. MOLNÁR EMMA főszerk., Absztrakció és valóság. Békési Imre köszöntése. JGyTF Kiadó, Szeged, 1996: 81-89.

DEME LÁszLó 1982. Közigazgatásunk nyelvi arculata. A Magyar Nyelvtudományi Társaság Kiadványai 162. Magyar Nyelvtudományi Társaság, Budapest.

DEME LÁszLó 1988. Átrétegződés vagy lepusztulás. In: KISS JENŐ - SzŰTS LÁsZLÓ szerk., A magyar nyelv rétegzödése: A Magyar Nyelvészek IV. Nemzetközi Kongresszusának elöadásai. Akadémiai Kiadó, Budapest. 251-260.

DEME LÁSZLÓ 1994. Nyelvünkröl, használatáról, használóiról. Tanulmányok. JGYTF Kiadó, Szeged.

DEME LÁszLó 2003. A szöveg természetéről és hangzásáról: tallózás négy évtized tarlóján. Kazinczy Ferenc Gimnázium, Győr. 
Deme LÁszló - FÁBiÁn PÁl - Tóth ETELKA szerk. 1988. Helyesirási kéziszótár. Akadémiai Kiadó, Budapest.

Deme LÁsZló - FÁBiÁn PÁl - Tóth Etelka szerk. 1999. Magyar helyesírási szótár. A Magyar Tudományos Akadémia szabályai szerint. Akadémiai Kiadó, Budapest.

DEME LÁSZLÓ - GRÉTSY LÁSZLÓ szerk. 1987. Iratszerkesztési és -fogalmazási tanácsadó. Közgazdasági és Jogi Könyvkiadó, Budapest.

DEME LÁSZló - GrétSY LÁSZló - WACHA IMRE 1987. Nyelvi illemtan. Ifjúsági Lap- és Könyvkiadó, Budapest. (Átdolgozott kiadása: 1999.)

DEME: Pályakép 2000 = Magyar nyelvész pályaképek és önvallomások 9. Deme László. Sorozatszerkesztő BOLLA KÁLMÁN. ELTE Fonetikai Tanszék, 2000: 9-31.

„Diófát ültetek” 2012 = Diófát ültetek, nem magamnak, hanem a késő utókornak. Emlékkötet Deme László nyelvészprofesszor tiszteletére. Szerk. WACHA IMRE. Kazinczy Ferenc Gimnázium, Győr.

„Diófát ültetek” 2021 = „Diófát ültetek...” Deme László emlékezete. Szerk. KovÁTs DÁNIEL VÁSÁRHELYI ZsUZSANNA. Anyanyelvápolók Szövetsége - győri Kazinczy Ferenc Gimnázium Az Iskoláért és az Anyanyelvért Alapítványa, Győr.

B. FEJEs KatAlin szerk. 2015. „Ha földbe szúrok tíz-húsz babkarót...”: Szemelvények Deme László nyelvészprofesszor személyes-szakmai írásaiból. Kazinczy Ferenc Gimnázium, Györ.

B. Fejes KATALIN - R. MolnÁR EMma szerk. 1996., Hipotézisek és realitások a lingvisztikában. Elöadások Deme László tiszteletére 75. születésnapja alkalmából. A Magyar Tudományos Akadémia Szegedi Területi Bizottsága, Szeged.

GulYÁs ZsuZSANNA 1996. Deme László munkássága 1981-től 1996-ig. Bibliográfia. In: B. FEJES KATALIN - R. MOLNÁR EMMA szerk., Hipotézisek és realitások a lingvisztikában. Előadások Deme László tiszteletére 75. születésnapja alkalmából. A Magyar Tudományos Akadémia Szegedi Területi Bizottsága, Szeged. 131-140.

KISS JENŐ 2012. A dialektológus Deme Lászlóról. In: „,Diófát ültetek” 2012: 41-46.

KISS JENŐ 2021. Centenáriumi emlékezés Deme Lászlóra, a dialektológusra. Magyar Nyelv 117: 199-202. https://doi.org/10.18349\%2FMagyarNyelv.2021.2.199

M. KORCHMÁROS VALÉRIA összeáll. 1991. Mondattan: kari jegyzet. JATEPress, Szeged.

MÁTÉ JAKAB 1991a. A magyar szövegtani kutatás mai helyzete 1. Szemiotikai Szövegtan 2: 73-116. MÁTÉ JAKAB 1991b. A magyar szövegtani kutatás mai helyzete 2. Szemiotikai Szövegtan 3: 105-143. MMNyR. = A mai magyar nyelv rendszere. Leiró nyelvtan. 1-2. Szerk. TOMPA JózSEF. Akadémiai Kiadó, Budapest, 1961-1962.

MNyA. = A magyar nyelvjárások atlasza 1-6. Szerk. Deme LÁszló - IMRE SAMU. Akadémiai Kiadó, Budapest, 1968-1977.

MGr. = Magyar grammatika . Szerk. KeSZLER BorBÁLA. Nemzeti Tankönyvkiadó, Budapest, 2000. SzABÓ JÓzSEF 1992. Deme László mint nyelvjáráskutató. Néprajz és Nyelvtudomány 34: 215-220.

TAKÁCS KÁROLYNÉ 1980. Deme László munkássága 1941-1980. Néprajz és Nyelvtudomány 24-25: 13-47.

VARGA LÁSZLÓ 1989. Szintaktikai szerkezet és intonációs tagolás a magyar mondategészben. Általános Nyelvészeti Tanulmányok 17: 241-278.

WACHA IMRE 2021. Deme László és az anyanyelvi mozgalmak. In: „Diófát ültetek” 2021: 121-133.

NAGY L. JÁNOS

Szegedi Tudományegyetem 